\title{
RETROSPECTIVE STUDY CORRELATION BETWEEN GRADE AND AMOUNT OF MITOSIS WITH ER, PR, AND HER2 EXPRESSION IN INVASIVE BREAST CARCINOMA OF NO SPECIAL TYPE
}

\author{
Rebecca Agustine Kristian, Willy Sandhika* \\ Department of Anatomical Pathology, RSUD Dr. Soetomo Surabaya/Faculty of Medicine, Universitas Airlangga, \\ Surabaya, Indonesia. \\ *Email: willysand@fk.unair.ac.id
}

\begin{abstract}
Background: In 2018 there were about 24.2\% new cases of breast carcinoma worldwide. Molecular breast carcinoma, like expression estrogen receptor (ER), progesterone receptor (PR), and Human Epidermal Growth Factor Receptor2 (HER2) have a higher sensitivity than morphological feature, like tumour grade and mitotic count as prognostic factors. The grade of the tumor reflects how similar these cells are to normal breast epithelial cells. The dominant growth pathway in normal breasts predominantly involves ER and PR, so tumours with ER and PR positivity show lower grade and proliferation activity. In contrast, tumours with ER and PR negativity often have more severe mutation, like overexpression of HER2.

Objective: To analyze the correlation between grade and mitotic count with ER, PR, and HER2 expression.

Methods: Analytical observational study with a retrospective design. This study used medical record data from ER, PR, and HER2 immunohistochemical examinations as well as histopathological grade and mitotic data for invasive breast carcinoma of no special type in the Anatomical Pathology Laboratory of Dr. Soetomo Surabaya for the period January 1, 2017 - December 31, 2019. Furthermore, the analysis of the relationship between grade and mitotic count was carried out with the expression of ER, PR, and HER2.

Results: There was a significant negative relationship between grade and ER with $r s=-0.170(p=0.000)$, the number of mitosis and ER with $r s=-0.010(p=0.001)$, grade and PR with $r s=-0.168(p=0.000)$, and the number of mitosis and PR with $\mathrm{rs}=-0.110(\mathrm{p}=0.000)$. There was no significant relationship between grade and HER2 $(\mathrm{p}=0.470)$ and the number of mitosis and HER2 ( $\mathrm{p}=0.279)$.

Conclusion: There is a negative significant relationship between grade and amount of mitosis with ER and PR expression. There is no significant relationship between grade and amount of mitosis with HER2 expression.
\end{abstract}

Keywords: breast carcinoma, grade, mitosis, ER, PR, HER2

\section{Introduction}

Breast cancer is the most common malignancy in women. In 2018, there were around $24.2 \%$ of new cases of breast cancer worldwide and about $30.9 \%$ of new cases in Indonesia (1). In the diagnosis of breast carcinoma, pathologists have become the link of the morphological features and protein expression of cancer cells. Prognosis factors in breast carcinoma can be determined from the morphological and molecular features. Morphologically, tumor size, grade, lymph node involvement, skin/chest wall involvement, histologic type, lymphovascular invasion, and surgical resection margins have been used extensively to determine prognosis $(2,3,4,5)$. Meanwhile, molecularly commonly used expressions are ER (Estrogen Receptor), PR (Progesterone Receptor), and HER2 (Human Epidermal Growth Factor Receptor 2) which were determined from immunohistochemical examination and ISH (In Situ Hybridization). Based on the expression of these proteins, breast carcinoma is divided into several molecular subtypes for prognostic purposes and determination of therapy. Not all cancers with the same stage have the same biological and behavioral characteristics $(2,6)$. Molecular information leads to different biological and etiologic pathways in cancer cell development (2).

The grade of breast carcinoma reflects how similar the tumor cells are to normal breast epithelial cells. In general, well-differentiated tumors behaved more calmly, while poorly differentiated tumors behaved more aggressively (7).

Normal breast epithelial cells use the steroid hormone estradiol for the development of the breast glands both in pre and post puberty, as well as during pregnancy, so that ER and PR are expressed in normal breast epithelial cells. (8). There are similarities between the development of normal breast tissue and the development of cancer at the molecular level. The development of normal breast tissue is tightly controlled by signaling pathways that allow cells 
to communicate with each other with the surrounding environment. It is not surprising that many of these same signaling pathways are regulated or hijacked by cancer cells (4). Low-grade breast cancer will be more like the cell of origin so that often positive ER and PR expression are obtained. On the other hand, in high-grade carcinoma cells, the cells are increasingly dissimilar to the original cells, so that negative ER and PR expressions are often obtained. In high-grade carcinoma cells, more severe mutations and higher genomic instability are often found, such as P53 mutations, amplification of HER2 (Human Epidermal Growth Factor Receptor 2), and BRCA1 dysfunction $(2,4)$ ). In normal breast epithelial cells, HER2 is very underexpressed, whereas in breast carcinoma, this receptor is overexpressed (9). The HER2 gene regulates the regulation of cell growth and signal transduction for cancer cell proliferation and differentiation (10).

Proliferation is related to the growth of tumor cells which can be seen through the number of mitoses and the expression of Ki67 (11). Usually, neoplasms that are highly proliferative (with multiple mitoses) have a poorer prognosis (12). The number of mitoses is one of the important components in determining the grade of breast carcinoma (11).

This retrospective study aims to determine the relationship between the grade and number of mitoses as prognostic factors morphologically with the expression of ER, PR, and HER2 as prognostic factors molecularly in invasive breast carcinoma of no special type.

\section{Material \& Methods}

The research design used was analytic observational with a retrospective cohort design that correlated the grade and number of mitoses in invasive breast carcinoma of no special type obtained from histopathological examination with ER, PR, and HER2 expression obtained from immunohistochemical examination. The research sample amounted to 1168 samples obtained by total sampling from medical record data in the Department of Anatomic Pathology of RSUD Dr. Soetomo Surabaya. Inclusion criteria included having a histopathological diagnosis in accordance with invasive breast carcinoma of no special type accompanied by a description of the grade and number of mitoses, and having immunohistochemical results for ER, PR, and HER2 antibodies. The exclusion criteria were samples from frozen section and samples with less-than-optimal preanalytic processes. The data is then processed in the SPSS Ver program. 26.

\section{Result}

\section{Grade Relationship with ER and PR Expression}

ER and PR expression in this study were observed in various grades of breast carcinoma. The grade and ER expression data were analyzed for normality of the data using the Kolmogorov test and showed that the data were not normally distributed $(\mathrm{p}<0,05)$. Then the Spearman correlation test analysis was performed, the relationship between tumor grade and ER expression showed that there was a significant relationship with $\mathrm{p}$ value $=0,000(\mathrm{p}$ value $<0,05)$ and correlation coefficient -0.170 . This suggests that the histological grade of breast carcinoma is inversely related to ER expression. At higher grades, lower ER expression is obtained. Data grade and PR expression were analyzed for normality of the data using the Kolmogorov test and showed that the data were not normally distributed $(\mathrm{p}<0,05)$. In the correlation test analysis with Spearman's test, the relationship between tumor grade and PR expression showed a significant relationship with $\mathrm{p}$ value $=0,000$ ( $\mathrm{p}$ value $<0,05)$ and correlation coefficient $-0,168$. This suggests that the histological grade of breast carcinoma is inversely related to PR expression. The higher the histological grade, the lower the PR expression. 


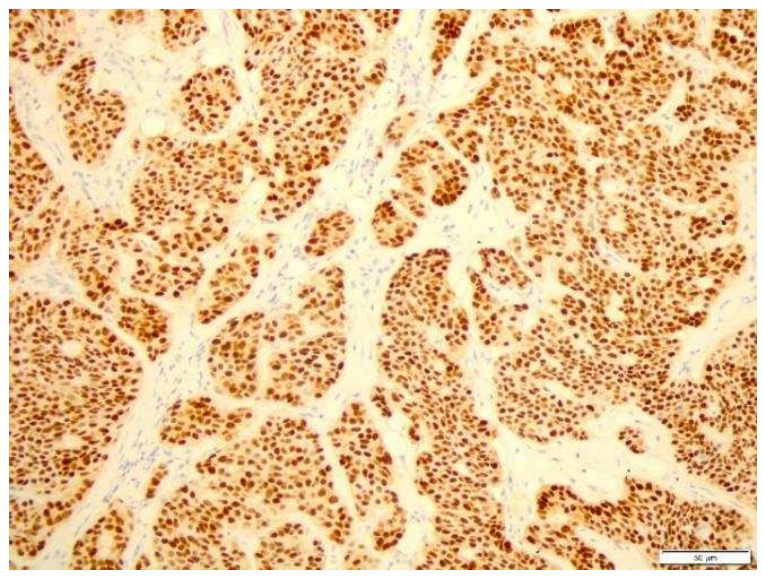

Figure 1. ER expression (IHC, 400x).

Table 1. Relationship between tumor grade and ER and PR expression

\begin{tabular}{|l|l|l|}
\hline & & Tumor grade \\
\hline ER expression & R & $-0,170$ \\
\hline & P & 0,000 \\
\hline & N & 1168 \\
\hline PR expression & R & -0.168 \\
\hline & P & 0,000 \\
\hline & N & 1168 \\
\hline
\end{tabular}

\section{Relationship between the number of mitoses and the expression of ER and PR}

The data on the number of mitoses and ER expression were analyzed for normality of the data using the Kolmogorov test and showed that the data were not normally distributed $(\mathrm{p}<0,05)$. Furthermore, Spearman correlation test analysis was performed, the relationship between the mitotic index and ER expression showed that there was a significant relationship with $\mathrm{p}$ value $=0,001$ ( $\mathrm{p}$ value $<0,05$ ) and correlation coefficient $-0,101$. This indicates that the mitotic index is inversely related to ER expression. The higher the mitotic index, the lower the ER expression. Mitotic index data and PR expression were analyzed for normality of the data using the Kolmogorov test and showed that the data were not normally distributed $(\mathrm{p}<0,05)$. In the correlation test analysis with the Spearman test, the relationship between the mitotic index and PR expression showed that there was a significant relationship with $\mathrm{p}$ value $=0.000$ ( $\mathrm{p}$ value $<0,05)$ and correlation coefficient $-0,110$. This shows that the mitotic index is related to PR expression, the higher the mitotic index, the lower PR expression.

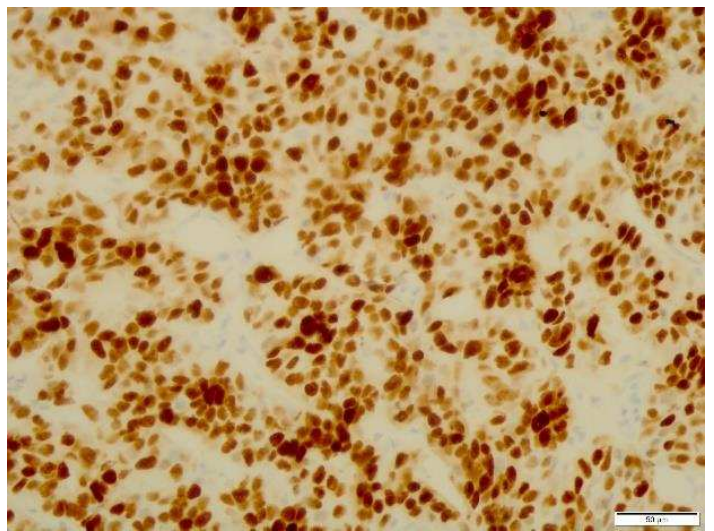

Figure 2. PR Expression (IHC, 400x). 
Table 2. Relationship of the number of mitoses with the expression of ER and PR

\begin{tabular}{|l|l|l|}
\hline & & Number of mitoses \\
\hline ER expression & $\mathrm{r}$ & $-0,101$ \\
\hline & $\mathrm{p}$ & 0,001 \\
\hline & $\mathrm{n}$ & 1168 \\
\hline PR expression & $\mathrm{r}$ & $-0,168$ \\
\hline & $\mathrm{p}$ & 0,000 \\
\hline & $\mathrm{n}$ & 1168 \\
\hline
\end{tabular}

\section{Relationship of Grade and Number of Mitosis with HER2 Expression}

HER2 expression in this study was observed in various grades of breast carcinoma. HER2 grade and expression data were analyzed for normality of the data using the Kolmogorov test and showed that the data were not normally distributed $(\mathrm{p}<0.05)$. In the correlation test analysis with Spearman's test, the relationship between tumor grade and HER2 expression showed a non-significant relationship with $\mathrm{p}$ value $=0,470$ ( $\mathrm{p}$ value $>0.05$ ). This indicates that the histological grade of breast carcinoma is not associated with HER2 expression. Mitotic index data and HER2 expression were analyzed for normality of the data using the Kolmogorov test and showed that the data were not normally distributed $(\mathrm{p}<0.05)$. In the correlation test analysis with the Spearman test, the relationship between the mitotic index and HER2 expression showed no significant relationship with $\mathrm{p}$ value $=0,279$ ( $\mathrm{p}$ value $>0.05$ ). This indicates that the mitotic index is not related to HER2 expression.

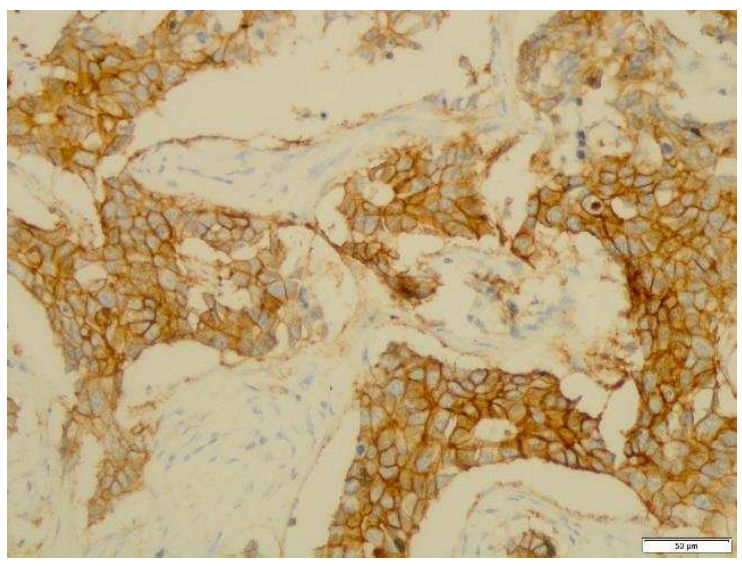

Figure 3. HER2 expression (IHC, 400x).

Table 3. Relationship between grade and number of mitoses with HER2 expression

\begin{tabular}{|l|l|l|}
\hline & & HER2 expression \\
\hline Tumor grade & $\mathrm{r}$ & 0,021 \\
\hline & $\mathrm{p}$ & 0,470 \\
\hline & $\mathrm{n}$ & 1168 \\
\hline Number of mitoses & $\mathrm{r}$ & 0,032 \\
\hline & $\mathrm{p}$ & 0,279 \\
\hline & $\mathrm{n}$ & 1168 \\
\hline
\end{tabular}




\section{Discussion \\ Grade relationship with ER and PR expression}

Prognosis factors in breast carcinoma can be determined from the microscopic and molecular images. Microscopic/morphological features, such as tumor size, grade, lymph node involvement, skin/chest wall involvement, histologic type, lymphovascular invasion, and surgical resection margins have been widely used to determine prognosis, as well as predict and select the type of therapy (3). While molecularly determined from immunohistochemical examination to see the expression of ER, PR, and HER2. Based on the expression of these proteins, breast carcinomas are divided into several molecular subtypes for prognostic purposes and therapeutic determination. Molecular determination of prognostic factors is more sensitive than microscopic and is "personalized prognostic and predictive testing" for determining targeted therapy. Not all cancers with the same stage have the same biological and behavioral characteristics $(2,6)$. Molecular information leads to different biological and etiologic pathways in cancer cell development (2).

The degree of differentiation of a tumor shows the resemblance of the tumor to the cells of origin. The better the degree of differentiation of a tumor (grade 1), the more similar it is to the cell of origin and tends to have a calm behavior. The worse the degree of differentiation (grade 3), the less similar it is to the original cell and usually has aggressive behavior. In general, patients with low-grade breast carcinoma (grade 1 or 2) have a good prognosis and survival rate (7).

This study reported that breast carcinomas with lower histopathological grades had more ER and PR expression. On the other hand, the higher the tumor grade, the lower the expression of ER and PR. This is in accordance with research which states that the presence of ER and PR expression is significantly associated with low histopathological degrees $(13,14,15)$. The existence of a significant negative relationship between ER and PR with grade indicates that the expression of ER and PR can be predicted from the morphological features of breast carcinoma.

There are similarities between the development of normal breast tissue and the development of cancer at the molecular level. The development of normal breast tissue is tightly controlled by complex signaling pathways that allow cells to communicate with each other. It is not surprising that many of these signaling pathways are regulated or hijacked by cancer cells and cancer stem cells. Genetic and epigenetic changes in cancer allow cells to deviate from normal mechanisms that control cell proliferation, survival and migration. These changes lead to signaling pathways that regulate cell proliferation, division, death, differentiation, fate, and motility, thereby activating mutations of protooncogenes and causing hyperactivation of these signaling pathways. In addition, there is also an inactivation of tumor suppressor genes that remove negative regulators of this signaling (4)

A univariate and multivariate cox study by Yang et al. (2020) reported that ER and PR expression are independent prognostic factors, where their use in determining prognosis does not require other clinical data. Breast carcinomas expressing ER and/or PR are termed luminal subtypes which have a better prognosis (4). Both of these receptors are involved in the most dominant signaling pathway in regulating normal breast gland development. Tumors with positive ER and PR are similar to normal breast cells, using the steroid hormones estradiol and progesterone as the main growth stimulus. PR expression is strongly dependent on ER expression. Tumors expressing PR but not expressing ER are very rare ( $<1 \%$ of breast carcinoma cases) (16). ER negative breast carcinomas increasingly do not resemble the cell of origin and tend to have more severe genetic mutations, such as p53, HER2, BRCA1 mutations and higher genomic instability (2,3). Low-grade breast carcinomas usually have positive ER and PR expressions like the cell of origin, so the expression of these two hormone receptors indicates a better prognosis, and has a lower grade $(15 \mathrm{c})$.

\section{Relationship between the number of mitoses and the expression of ER and PR}

Genes expressed in high-grade breast cancer are associated with cell cycle and cell proliferation. One of the classical measurements of tumor cell proliferation is using the number of mitoses. A high mitotic rate is a poor prognosis with an increased recurrence and mortality rate $(17,18)$.

Tumors with positive ER and PR are more similar to normal breast cells, using the steroid hormones estradiol and progesterone as the main growth stimulus (4). In this study, it was found that breast carcinomas with lower proliferative indices had more ER and PR expression. On the other hand, the higher the proliferation index, the lower the expression of ER and PR. This is in accordance with several studies which state that the presence of ER and PR expression is significantly associated with a low proliferation index $(13,14,15)$. Estrogen receptor status has been widely reported to be inversely correlated with the number of mitoses (19). The higher the estrogen receptor status, the lower the tumor cell proliferation (19c). The existence of a significant negative relationship between ER and PR with the number of mitoses indicates that the expression of ER and PR can be predicted from the morphological features of breast carcinoma. 


\section{Relationship of grade and amount of mitosis with HER2 expression}

HER2 is a member of the transmembrane receptor tyrosine kinase family that functions in cell growth, proliferation and normal cell division (21). On the surface of normal breast cells, HER2 is expressed in small amounts. HER2 signaling is amplified in breast cancer cells resulting in overexpression of the HER2 protein associated with tumor cell proliferation and cancer progression (22). In contrast to ER and PR, HER2 overexpression is associated with poorer prognosis, higher tumor grade, and higher proliferative index values $(23,24)$.

In this study, there was no significant relationship between HER2 overexpression with grade and number of mitoses. This is in contrast to the theory that there is a relationship between HER2 and the number of mitoses. The higher the degree of differentiation and the number of mitoses, the higher the expression of HER2 protein $(4,23,24)$.

This study is in line with several studies which also stated that there was no significant relationship between HER2 overexpression and grade $(21,25,26)$ and mitosis $(27)$. This may indicate that HER2 is a prognostic factor whose expression cannot be predicted from the morphological features of breast carcinoma.

Breast carcinomas with HER2 overexpression can have both positive and negative ER expression. The HER2-positive and ER-positive groups are termed luminal molecular subtype B and have a better prognosis with lower morphological grade and number of mitoses, but worse than luminal subtype A (HER2 negative, ER positive). The HER2 positive and ER negative groups are called the HER2 enriched subtype. This subtype has a poorer prognosis and a higher grade and number of mitoses than the luminal subtype $(4,6)$. In breast carcinoma cells with HER2 negative, ER negative and PR negative can also be obtained which is called the triple negative molecular subtype. This subtype is due to more severe genetic aberrations, such as p53 and BRCA1 mutations, as well as high genomic instability, so that even though they have negative HER2, these breast carcinoma cells have a higher grade and number of mitoses $(2,28)$.

HER2 examination is mandatory for prognostic purposes in all breast carcinomas because positive and negative HER2 results cannot be seen from the morphological picture of breast carcinoma. Morphologically, HER2 positive and negative can be found in low-grade and high-grade breast carcinomas, and low or high mitotic counts.

\section{CONCLUSION}

There is a significant negative relationship between grade and expression of ER and PR in invasive breast carcinoma of no special type. There is a significant negative relationship between the number of mitoses and the expression of ER and PR in invasive breast carcinoma of no special type. There is no significant relationship between grade and number of mitoses with HER2 expression in invasive breast carcinoma of no special type.

\section{REFERENCES}

1. Globocan Observatory, W. (2019) 'Cancer Today - World', International Agency for Research on Cancer, 876, pp. 2018-2019. Available at: https://gco.iarc.fr/today/data/factsheets/populations/900-world-factsheets.pdf.

2. Allison, K. H. (2012) 'Molecular pathology of breast cancer: What a pathologist needs to know', American Journal of Clinical Pathology, 138(6), pp. 770-780. doi: 10.1309/AJCPIV9IQ1MRQMOO.

3. Dai, X., Xiang, L., Li, T., Bai, Z. (2016) 'Cancer hallmarks, biomarkers and breast cancer molecular subtypes', Journal of Cancer, 7(10), pp. 1281-1294. doi: 10.7150/jca.13141.

4. Feng, Y.. Spezia, M., Huang, S., Yuan, C., Zeng, Z Zhang, L., et al. (2018) 'Breast cancer development and progression: Risk factors, cancer stem cells, signaling pathways, genomics, and molecular pathogenesis', Genes and Diseases. Elsevier Ltd, 5(2), pp. 77-106. doi: 10.1016/j.gendis.2018.05.001.

5. Li, Y.. Cao, J., Zhou, Y., Mao, F., Shen, S., dan Sun, Q. (2019) 'Mammographic casting-type calcification is an independent prognostic factor in invasive breast cancer', Scientific Reports. Springer US, 9(1), pp. 1-9. doi: 10.1038/s41598-019-47118-3.

6. Toss, A. dan Cristofanilli, M. (2015) 'Molecular characterization and targeted therapeutic approaches in breast cancer', Breast Cancer Research, 17(1), pp. 1-11. doi: 10.1186/s13058-015-0560-9.

7. Rakha, E. A.. Reis-Fiho, J. S., Baehner, F, Dabbs, D. J., Thomas, D., Vincenzo, E., et al. (2010) 'Breast cancer prognostic classification in the molecular era: The role of histological grade', Breast Cancer Research, 12(4). doi: $10.1186 / \mathrm{bcr} 2607$

8. Tanos, T.. Rojo, L. J., Echeverria, P. dan Brisken, C. (2012) 'ER and PR signaling nodes during mammary gland development', Breast Cancer Research, 14(4). doi: 10.1186/bcr3166.

9. Margan, M. M., Jitariu, A. A., Cimpean, A. M., Nica, C., dan Raica, M. (2016) 'Molecular portrait of the normal human breast tissue and its influence on breast carcinogenesis', Journal of Breast Cancer, 19(2), pp. 99-111. doi: 10.4048/jbc.2016.19.2.99. 
10. Aini, N., Kasno dan Basuki, R. (2015) 'Hubungan antara Ekspresi Protein Her-2/Neu dengan Derajat Diferensiasi Penderita Karsinoma Payudara Jenis Duktus Invasif’, Jurnal Kedokteran Muhammadiyah Volume 2 Nomor 1, pp. 12-15.

11. Bertucci, F., Finetti, P., Roche, H. (2013) 'Comparison of the prognostic value of genomic grade index, Ki67 expression and mitotic activity index in early node-positive breast cancer patients', Annals of Oncology. Elsevier Masson SAS, 24(3), pp. 625-632. doi: 10.1093/annonc/mds510.

12. Bonert, M. dan Tate, A. J. (2017) 'Mitotic counts in breast cancer should be standardized with a uniform sample area', BioMedical Engineering Online. BioMed Central, 16(1), pp. 1-8. doi: 10.1186/s12938-0160301-z.

13. Sheikhpour, R. dan Poorhosseini, F. (2016) 'Relation between estrogen and progesterone receptor status with p53, ki67 and her-2 markers in patients with breast cancer', Iranian Journal of Blood and Cancer, 8(4), pp. 93-97.

14. Khanna, S. P. dan Rigvardhan, R. (2018) 'Correlation of Histological Grade with Harmone Receptors and Her 2 Neu In Carcinoma Breast - A Tertiary Centre Study', International Journal of Contemporary Medical Research [IJCMR], 5(5), pp. 6-8. doi: 10.21276/ijcmr.2018.5.5.33

15. Shrestha, G., Satyal, B. dan Sherpa, P. (2019) 'Correlation of histological grade with Estrogen, Progesterone and HER 2/neu reactivity in breast cancer', Journal of Pathology of Nepal, 9(2), pp. 1518-1522. doi: 10.3126/jpn.v9i2.24963.

16. Atif, N. (2018) 'Role of immunohistochemical markers in breast cancer and their correlation with grade of tumour, our experience', International Clinical Pathology Journal, 6(3), pp. 141-145. doi: 10.15406/icpj1.2018.06.00175.

17. Kheirandish, S. dan Homaee, F. (2015) 'Ki-67 protein: a proliferation index in breast cancer', Mashhad University of Medical Sciences, 2(4), pp. 205-208. doi: 10.17463/RCM.2015.04.010.

18. Rossi, L.. Laas, E., Mallon, P., Vincent, S. A., Guinebretiere, J. M., Lerebours, F., Rouzier, R., Pierga, J. Y., dan Reyal, F. (2015) 'Prognostic impact of discrepant Ki67 and mitotic index on hormone receptor-positive, HER 2-negative breast carcinoma', British Journal of Cancer. Nature Publishing Group, 113(7), pp. 9961002. doi: 10.1038/bjc.2015.239.

19. Urruticoechea, A., Smith, I. E. dan Dowsett, M. (2005) 'Proliferation marker Ki-67 in early breast cancer', Journal of Clinical Oncology, 23(28), pp. 7212-7220. doi: 10.1200/JCO.2005.07.501.

20. Thiygarajan, M., Navrathan, N., Mohanapriya, T., Kumar, A., Singh, B. (2015) 'Correlation between estrogen receptor, progesterone receptor, HER-2/neu status and other prognostic factors in carcinoma breast in Indian population', International Surgery Journal, 2(4), pp. 515-522. doi: 10.18203/23492902.isj20151000.

21. Warjianto, W.. Soewoto, W., Alifinto, U., Wujoso, H. (2020) 'Hubungan Reseptor Estrogen, Reseptor Progesteron dan Ekspresi Her-2/Neu Dengan Grading Histopatologi pada Pasien Kanker Payudara di RSUD dr. Moewardi Surakarta', Smart Medical Journal, 3(2), p. 96. doi: 10.13057/smj.v3i2.35228.

22. Iqbal, N dan Iqbal, N. (2014) 'Human Epidermal Growth Factor Receptor 2 (HER 2) in Cancers: Overexpression and Therapeutic Implications', Molecular Biology International, 2014, pp. 1-9. doi: $10.1155 / 2014 / 852748$.

23. Shokouh, T. Z.. Ezatollah, A., Barand, P., dan Yang, F. (2015) 'Interrelationships between Ki67, HER 2/neu, p53, ER, and PR status and their associations with tumor grade and lymph node involvement in breast carcinoma subtypes: Retrospective-observational analytical study', Medicine (United States), 94(32), pp. 16. doi: 10.1097/MD.0000000000001359.

24. Rakha, E. A., Allison, K. H., Bu, H., Ellis, I. O., Foschini, M. P., Horri, R., Masuda S., et al. (2019) Breast Tumours. 5th edn. Edited by WHO Classification of Tumours Editorial Board. Lyon: IARC Library Cataloguing in Publication Data.

25. Dayal, A., Shah, R. J., Kothari, S., dan Patel, S. M. (2016) 'Correlation of Her-2/neu status with estrogen, progesterone receptors and histologic features in breast carcinoma', Annals of Pathology and Laboratory $\begin{array}{lllll}\text { Medicine, } & 3(5), & \text { p. } & 8 . & \text { Available }\end{array}$ at:https://pdfs.semanticscholar.org/a83f/06d00cd9946ef3391319e7c86130ec9cebde.pdf.

26. Juneja, S.. Agarwal, R., Agarwal, D., Rana, P., Singh, K., Kaur, S. (2019) 'Correlation of Expression of Estrogen Receptor, Progesterone Receptor and Human Epidermal Growth Factor Receptor-2 with Histopathological Grade in Cases of Carcinoma Breast', International Journal of Contemporary Medical Research [IJCMR], 6(9). doi: 10.21276/ijcmr.2019.6.9.26.

27. Setiawati, Y.. Agus, S., Asri, A., Tofrizal, T. (2019) 'Hubungan Ekspresi Topo2a dan Her-2 dengan Faktor Prognostik Histopatologik Karsinoma Payudara Invasif Tidak Spesifik’, Jurnal Kesehatan Andalas, 8(2S), 
p. 64. doi: $10.25077 /$ jka.v8i2s.961.

28. Setiawati, Y.. Agus, S., Asri, A., Tofrizal, T. (2019) 'Hubungan Ekspresi Topo2a dan Her-2 dengan Faktor Prognostik Histopatologik Karsinoma Payudara Invasif Tidak Spesifik', Jurnal Kesehatan Andalas, 8(2S), p. 64. doi: $10.25077 /$ jka.v8i2s.961. 